\title{
Skim Milk Flocculation Concentrates White Spot Syndrome Virus in Seawater for Detection Using A Monoclonal Antibody Based Flow-Through Assay
}

Camerson Donald Ghambi ${ }^{{ }^{*}, 2}$, Shankar Mariyappa Kalkuli ${ }^{1}$, Prakash Patil ${ }^{* 1,3}$, Satish Rama Poojary ${ }^{1}$, Abhiman Ballyaya ${ }^{1}$, Naveen Kumar Thammegouda ${ }^{1,4}$ and Ramesh Kashi Srinivasayya ${ }^{1}$

${ }^{1}$ Aquatic Animal Health Management Laboratory, Department of Aquaculture, College of Fisheries, Karnataka Veterinary Animal and Fisheries Science University, Mangaluru, 575002, Karnataka, India

${ }^{2}$ Department of Aquaculture, Bunda College of Agriculture, Lilongwe University of Agriculture and Natural Resources, Lilongwe, Malawi

${ }^{3}$ SDM Biomedical Research Center, SDM College of Medical Sciences \& Hospital, 580009, Karnataka, India

${ }^{4}$ Fish Biotechnology and Aquatic Health Management Laboratory, Department of Aquatic Environment, College of Fisheries, GADVASU, Ludhiana 141001, Punjab, India

Received: February 14, 2018; Accepted: May 1, 2018; Published: May 22, 2018

*Corresponding author: Camerson Donald Ghambi, Department of Aquaculture, Lilongwe University of Agriculture and Natural Resources, P.O. Box 219, Lilongwe, Malawi, Africa, Tel: +265 999330336/888976996; Fax: +265 1277364; Email: camerson1982@gmail.com

\begin{abstract}
Since its emergence, white spot syndrome virus has caused huge loss to shrimp aquaculture. However, these viruses are present in very low copy number in water and hence, concentrating them prior to detection is very much essential. In the present study, skim milk $(0.01 \%)$ was employed for one step concentration of white spot syndrome virus from seawater under acidic $(\mathrm{pH} 3.5)$ and neutral (pH 7.4) conditions. The concentrated virus was detected using a monoclonal antibody based flow-through assay, RapiDot and compared its performance with Polymerase Chain Reaction (PCR). In an invitro experiment, the recombinant VP28 protein of white spot syndrome virus was flocculated successfully by skim milk in $50 \mathrm{~mL}$ measuring cylinders and detectable in both sub-surface and floc samples by RapiDot. Further, these results were validated by experimental infection studies using virus infected water for skim milk flocculation and detected the virus in floc samples 6 h earlier by RapiDot, compared to 1-step PCR. Overall, a simple method to concentrate white spot syndrome virus in water by skim milk flocculation for detection by RapiDot has been developed and may be adaptable to field conditions.
\end{abstract}

Keywords: Detection; Flocculation; RapiDot; Recombinant VP28 protein; Skim milk; White spot syndrome virus;

\section{Introduction}

The increase in demand of shrimp due to improved incomes among the ever increasing population has led to the expansion and intensification of shrimp aquaculture globally [1-3]. With the quest to satisfy this demand, many shrimp farmers fail to uphold best management practices in aquaculture resulting to deterioration of water quality and subsequently disease outbreaks. Viral diseases have posed severe threats to shrimp aquaculture [4]. Till date, of the several viral diseases, white spot disease caused by White Spot Syndrome Virus (WSSV) has been notorious and devastative, incurring more than 15 billion USD loss to the shrimp industry [5,6]. VP28 protein is one of the major coat proteins of WSSV that implicates in virulence $[7,8]$. WSSV is an envelope, bacilliform, double-stranded DNA virus $[9,10]$; transmit through vertical and horizontal route and also through carrier organisms $[11,12]$. At present, the rate at which WSSV outbreaks have reached places that were deemed as WSSV free zones is alarming and of great concern [13,14]. However, transmission of WSSV through water is probably the major route of entry into the culture system hence, regular monitoring by checking the water before pumping into ponds for managing the WSSV entry is very much essential [15-17]. Passive diagnosis of viruses in sick animals using molecular tools cannot predict future outbreaks hence; the study of the epidemiology of viruses in the environmental water becomes imperative. However, the bottleneck to virus detection in environmental water is that their copy numbers are extremely low and can hardly be detected by conventional PCR, thus concentrating virus particles should become obligatory prior to their detection [18-21].

Virus concentration and detection methods in water are many $[18,22,23]$ however protocols that have been developed for WSSV include tangential flow ultra filtration [24] followed by nested PCR (Polymerase Chain Reaction) and qPCR detection, combined ferric colloid adsorption and foam separation [25] 
followed by PCR detection, centrifugation [26] and membrane filtration [27] followed by PCR detection. Recently, [28] used inorganic flocculent, alum at 15 and $30 \mathrm{ppm}$ to concentrate WSSV from water and detected successfully by monoclonal antibody based flow-through assay, RapiDot and PCR. However, most of these methods employed to concentrate WSSV are costly, may result in loss of virus particles and also not farmer friendly. Moreover, inorganic flocculents result in secondary pollution which is harmful to the environment. Alternatively, the ecofriendly organic flocculents are found to be more advantageous as they are biodegradable and lead to faster floc formation because of their high settling velocity $[29,30]$. In this study, skim milk has been employed as an organic flocculent to concentrate WSSV in seawater and its detection using a monoclonal antibody based RapiDot test, compared with PCR. Overall, the results obtained from invitro experiments and experimental infection studies, indicate that WSSV in seawater could be easily flocculated by skim milk for detection by monoclonal antibody based RapiDot.

\section{Materials and Methods}

\section{Source of white spot syndrome virus (WSSV)}

Shrimp (Penaeus vanammei) with white spots were collected from a farm in Kannur District, Kerala, and transported on ice to the Aquatic Animal Health Management Laboratory, College of Fisheries, Mangaluru. WSSV infection in shrimp was confirmed by PCR $[31,32]$. Similarly, wild shrimp were collected from fish landing centre, Mangaluru for the preparation of negative control. A pair of pleopods and gills of each shrimp were fixed in absolute methanol and assayed for WSSV by nested PCR (nPCR).

\section{Confirmation of WSSV infection in shrimp by} polymerase chain reaction (PCR)

DNA extraction: Gills and pleopods from shrimp were used for DNA extraction according to DNA express kit (Himedia). Briefly, $50 \mathrm{mg}$ of pleopods and gills were homogenised in 1 mL DNA express reagent using micro pestle in a $1.5 \mathrm{~mL}$ microcentrifuge tube. $1 \mathrm{~mL}$ chloroform was added and the homogenate was centrifuged at $10,000 \times \mathrm{g}$ for $10 \mathrm{~min}$ at Room Temperature (RT). $1 \mathrm{~mL}$ ethanol was added and centrifuged at 5,000 $\mathrm{x}$ g for 4 min at RT. The supernatant was decanted and the pellet washed in ethanol and further centrifuged at 12,000 x g for 2 min. Finally, the pellet was solubilised in $50 \mu \mathrm{l}$ Tris-EDTA (TE) buffer.

First-step and nested PCR: In the first-step PCR, one $\mu$ l of DNA extract was added to PCR tube containing $29 \mu \mathrm{l}$ of PCR reaction mixture from Genei, Bangalore (75 mMTris- $\mathrm{HCl} \mathrm{pH}$ 9.0, $20 \mathrm{mM}\left(\mathrm{NH}_{4}\right)_{2} \mathrm{SO}_{4}, 0.01 \%$ Tween $20,1.5 \mathrm{mM} \mathrm{MgCl}_{2}, 200 \mu \mathrm{M}$ of each dNTP, 1.5 units of Taq DNA polymerase) and (100 pM of each primers (146F1/146R1) BioServe, Hydrabad. The primer sequence of $146 \mathrm{~F} 1$ is $5^{\prime}$-ACTACTAACTTCAGCCTATCTAG-3' and 146R1 is 5'-TAATGCGGGTGTAATGTTCTTACGA-3'. The First round DNA amplification was performed using C1000 Touch Thermo cycler (Biorad) by subjecting the reaction mixture to initial denaturation of $94^{\circ} \mathrm{C}$ for $5 \mathrm{~min}$, followed by 30 cycles of amplification (denaturation, $94^{\circ} \mathrm{C} / 90 \mathrm{sec}$; annealing, $55^{\circ} \mathrm{C} / 180 \mathrm{sec}$; extension, $72^{\circ} \mathrm{C} / 90 \mathrm{sec}$ and a final extension at $72^{\circ} \mathrm{C}$ for $5 \mathrm{~min}$ ).
In the nested PCR, two $\mu$ first-step PCR product was added to PCR tube containing $18 \mu \mathrm{l}$ of PCR reaction mixture $(200 \mu \mathrm{M}$ of each dNTP, $100 \mathrm{pM}$ of 146F2, $100 \mathrm{pM}$ of 146R2, 1.5 units of Taq polymerase, Taq buffer with $1.5 \mathrm{mM} \mathrm{MgCl}_{2}$ ) and subjected to similar amplification conditions as above. The primer sequence of $146 \mathrm{~F} 2$ is $5^{\prime}$-GTAACTGCCCCTTCCATCTCCA-3' and 146R2 is 5'-TACGGCAGCTGCTGCACCTTGT-3'. The positive control (previously tested 1-step PCR positive WSSV infected shrimp pleopods and gills) and negative control (previously tested nested PCR negative normal shrimp pleopods and gills) were treated similarly along with the samples. The PCR products were electrophoresed onto $1.5 \%$ agarose gel under Tris Acetate-EDTA (TAE) buffer (Trizma base, acetic acid and EDTA, pH 8.5) at $120 \mathrm{~V}$ for $60 \mathrm{~min}$. The PCR amplicons were visualised under U.V. transilluminator (Biorad).

\section{Recombinant VP28 protein (rVP28) of WSSV preparation and purification}

The recombinant His-tagged VP28 protein containing plasmid construct, pET28a in DH5 $\alpha$ E. coli cells was received from Prof. Just M Vlak, Wageningen University, The Netherlands as courtesy and stored at $-80^{\circ} \mathrm{C}$ and prepared according to [33] and purified using Ni-NTA (Nickel-nitrilotriacetic acid) column following manufacturer's instructions(Qiagen, USA). In brief, cells harvested by centrifugation (11000 x g for $5 \mathrm{~min}$ ) were lysed in $700 \mu \mathrm{l} 7 \mathrm{M}$ Urea pH 8.0 by keeping at RT for 15 min under agitation.This cell lysate was centrifuged at $12000 \mathrm{x}$ g for $15 \mathrm{~min}$ at RT, the clarified cell lysate (about $600 \mu \mathrm{l}$ ) containing His-tagged protein was loaded onto a Ni-NTA spin column and centrifuged at $270 \mathrm{x} \mathrm{g}$ for $5 \mathrm{~min}$. After thorough washing of spin column with $8 \mathrm{M}$ Urea $\mathrm{pH} 6.3$, the spin column was centrifuged at $890 \mathrm{x}$ $\mathrm{g}$ for $2 \mathrm{~min}$ to elute purified proteins and the elution was done twice in $200 \mu \mathrm{l} 8 \mathrm{M}$ urea $\mathrm{pH} 4.5$. Dialysed eluted proteins for $7 \mathrm{~h}$ at $4^{\circ} \mathrm{C}$ were concentrated and stored at $4^{\circ} \mathrm{C}$. The protein content of this purified VP28 was quantified using the A280 method by NanoDrop 2000c spectrophotometer (Thermo Scientific, USA) following the suppliers instructions.

\section{RapiDot Analysis of rVP28 proteinof WSSV}

RapiDot was carried out according to [34] briefly, an aliquot $(\sim 0.2 \mu \mathrm{l})$ each of VP28 protein $(0.5 \mu \mathrm{g} / \mu \mathrm{l})$, estimated using the A280 method as positive and PBS buffer as negative control were dotted onto the upper part of the nitrocellulose membrane in the cassette while the sub-surface and floc samples were dotted onto the lower part. The membrane was air dried for $5 \mathrm{~min}$ and thereafter treated stepwise in sequential order with $200 \mu \mathrm{l}$ each reagent including blocking buffer (2\% BSA in PBS), one week old cell culture supernatant of MAb (C-05), wash buffer (6\% Tween 20 in PBS), rabbit anti mouse IgG-HRP (1:500 in 2\% BSA in PBS), wash buffer and 3,3', 5, 5'-Tetramethylbenzidine (TMB) $/ \mathrm{H}_{2} \mathrm{O}_{2}$ (Sigma, USA) as a precipitating chromogen-substrate. Finally, the reaction was terminated by adding $400 \mu \mathrm{l}$ of wash buffer. The development of varied intensities of purple blue dots for different samples were recorded and compared with positive and negative control. 


\section{Experimental set up for concentrating rVP28 protein of WSSV in seawater by skim milk flocculation}

To concentrate recombinant VP28 by skim milk flocculation, column purified rVP28 protein was serially diluted to $10^{-10}$ in 0.2 $\mu \mathrm{m}$ nitrocellulose membrane filtered seawater ( $\mathrm{pH} 7.4$, salinity $36 \mathrm{ppt}$, temperature $25.7^{\circ} \mathrm{C}$ ). One microliter from each dilution was analysed by 1-step PCR [35] and RapiDot [34]. The sequences of primers used to amplify the recombinant VP28 transcript of WSSV are F; 5'CGCGGATCCGATGGATCTTTCTTTCACTCTTTC3'and R; 5'-CCGGAATTCTTACTCGGTCTCAGTGCCAG-3'. The lowest dilution at which RapiDot detected the rVP28 was tested for concentrating the rVP28 protein by skim milk flocculation. $0.5 \mathrm{~mL}$ of purified rVP28 protein from the stock was added to a $100 \mathrm{~mL}$ beaker containing $100 \mathrm{~mL}$ filtered seawater, mixed with $0.01 \%$ skim milk. After thorough mixing for at least $10 \mathrm{~min}$, the seawater samples were uniformly distributed into four $50 \mathrm{~mL}$ measuring cylinders, and kept undisturbed to allow flocculation of rVP28 protein by gravity. The experiments were conducted under acidic (pH 3.5) and neutral (pH 7.4) conditions in duplicate. At every $2 \mathrm{~h}$ interval for the initial $12 \mathrm{~h}$ period and $6 \mathrm{~h}$ interval till $36 \mathrm{~h}$ period, samples from sub-surface ( $1 \mathrm{~cm}$ below from the surface) and floc that is deposited at the bottom in each experimental conditions were collected using sterile sucker pipettes. The floc samples were centrifuged at $10,000 \mathrm{xg}$ for $15 \mathrm{~min}$ at $4^{\circ} \mathrm{C}$ and the resultant pellet was re-suspended in $100 \mu \mathrm{lBS}$, labeled and stored at $4^{\circ} \mathrm{C}$ for further analysis. All the sub-surface and floc samples were analysed by RapiDot [34] and directly (without performing DNA extraction) by PCR as described above [35].

\section{Experimental infection of WSSV}

Healthy Penaeus monodon were collected from a farm near Kumta, Karnataka, India and acclimatised to the laboratory conditions for a week. Three shrimps ( $\sim 15 \mathrm{~g}$ each) based on the stocking density practiced in Andrapradesh, India by shrimp farmers, were stocked in aquarium tanks containing $25 \mathrm{~L}$ seawater (salinity 16 ppt, specific gravity $1.011, \mathrm{pH} 7.4$, temperature $28^{\circ} \mathrm{C}$ ) with continuous aeration. Shrimps were injected with $100 \mu \mathrm{g}$ of semi-purified WSSV at the lateral position of third abdominal segment using $1 \mathrm{~mL}$ insulin syringe fitted with 30G x 5/16 $(0.30 \times 8 \mathrm{~mm})$ needle. The injected shrimps were fed daily with commercial diet at 5\% body weight and monitored daily for the development of clinical white spots on carapace and mortality. Semi-purified WSSV $(2.93 \mu \mathrm{g} / \mu \mathrm{l})$ was prepared from the dead shrimps according to [36] and added back into the aquaria from which water samples were collected in different laboratory glassware ( 2 and $1 \mathrm{~L}$ beakers, and $50 \mathrm{~mL}$ measuring cylinders) in duplicate for concentrating WSSV by skim milk flocculation as per the protocol previously explained. The WSSV in the sub-surface and bottom floc samples was analysed by RapiDot and directly (without performing DNA extraction) by1-step and nested PCR as previously described.

\section{Results}

\section{Confirmation of WSSV in infected shrimp}

The homogenate prepared from Penaeus vannamei with white spots (Figure 1a) were found positive for WSSV by 1-step and nested PCR (Figure 1b). The appearance of 1447 and $941 \mathrm{bp}$ amplicons in 1-step and nested PCR products, respectively, when electro phoresed on $1.5 \%$ agarose gel electrophoresis re-affirmed the presence of WSSV in shrimp. The preparations from normal shrimp showed no amplification of WSSV specific amplicons by nested PCR

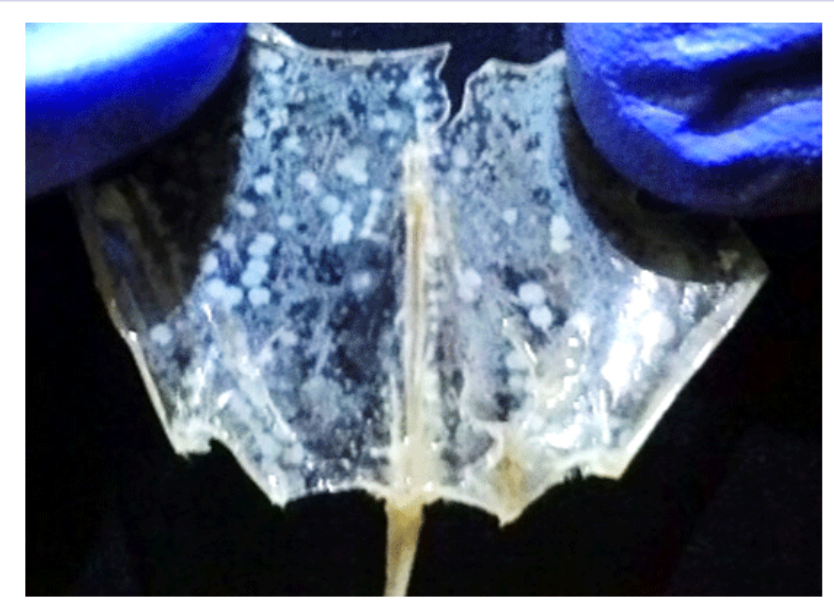

Figure 1a: Presence of white spots (arrow heads) on the carapace of suspected shrimp samples.

b.

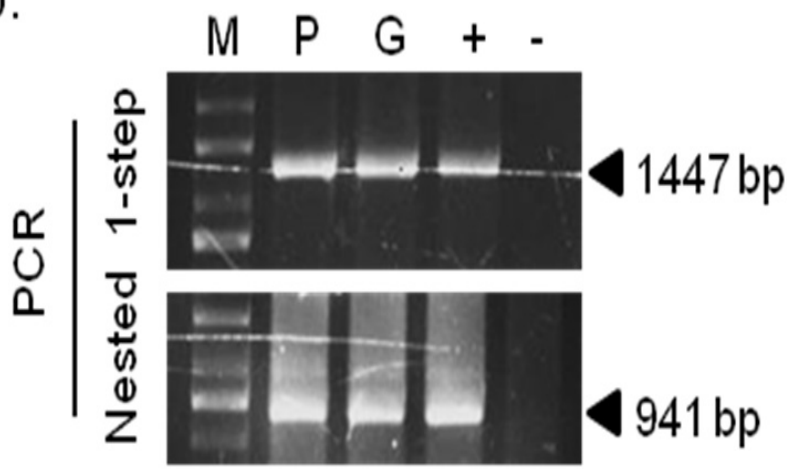

Figure 1b: Confirmation of WSSV in shrimp by PCR. Amplification of WSSV-specific gene of 1447 bp by 1-step and 941 bp by nested PCR in the suspected shrimp samples. Lanes: M, Molecular marker P, Pleopods; G, Gills; +, Positive control; and -, Negative control.

\section{Skim milk concentrates rVP28 protein of WSSV to floc in seawater}

Each log dilution of the purified WSSV rVP28 protein stock was analysed by RapiDot and found that the WSSV was detectable up to $10^{-7}$ dilution (Figure 1c). The estimated concentration of rVP28 protein in the $\left(10^{-7}\right)$ dilution was used to find the volume taken from the rVP28 stock using the dilution formula, for further use in the skim milk $(0.01 \%)$ flocculation experiment. The rVP28 protein was detectable by RapiDot (Figure 2a) and the rVP28 transcript by PCR at 615 bp (Figure 2b) in sub-surface samples, in 


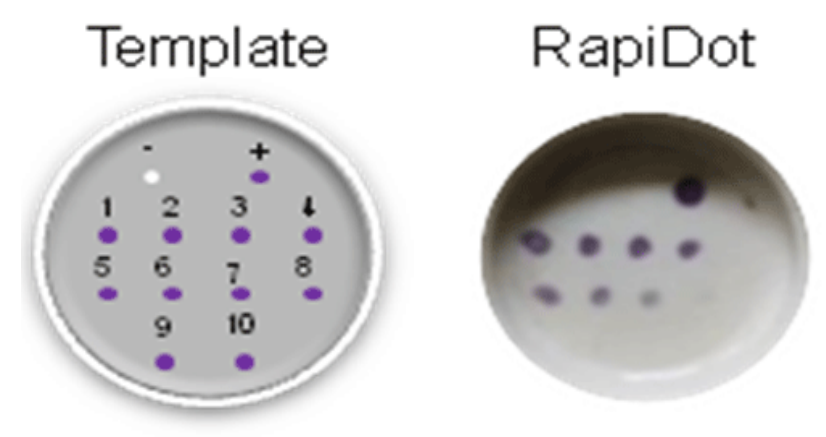

Figure 1c: RapiDot analysis of log diluted samples of the recombinant VP28 protein stock. Appearance of purple blue dots showing the presence of the recombinant VP28 protein in log diluted samples by RapiDot. The order is -, Negative control, +, Positive control and log dilution from $10-1$ to $10-10$ of the recombinant VP28 protein from stock; depicted as numbers in the template.

which virus protein was flocculated by $0.01 \%$ skim milk. RapiDot detected the rVP28 protein with low intense dots from $0 \mathrm{~h}$ to18 $\mathrm{h}$ in acidic and $0 \mathrm{~h}$ to $36 \mathrm{~h}$ in neutral conditions. PCR detected the rVP28 transcript with very faint bands in acidic conditions at $4 \mathrm{~h}$, while in neutral conditions at $2 \mathrm{~h}$ and also $12 \mathrm{~h}$ to $30 \mathrm{~h}$ respectively. However, the dot intensity in RapiDot was better in sub-surface samples from neutral seawater conditions, compared to acidic conditions.

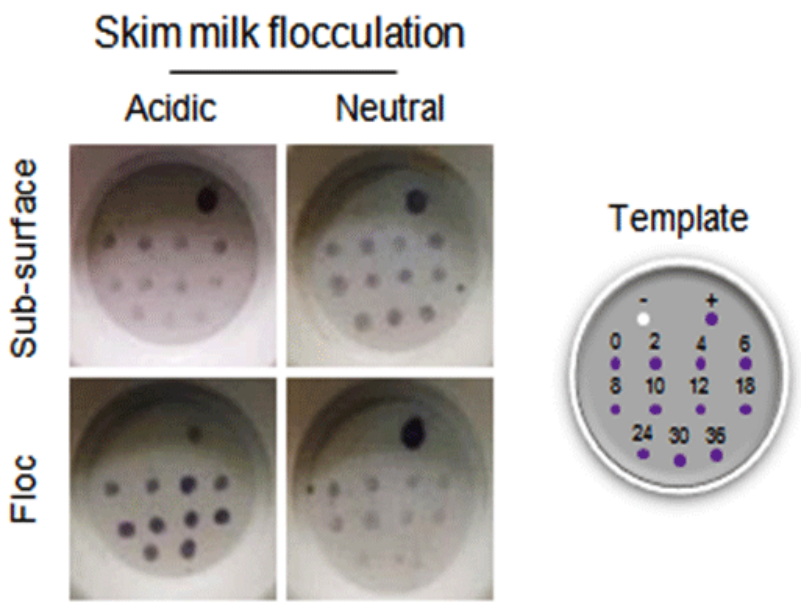

Figure 2a: RapiDot analysis of the recombinant VP28 concentrated by skim milk flocculation in sub-surface and floc samples. Appearance of purple blue dots showing the presence of the recombinant VP28 protein in sub-surface and floc samples under acidic and neutral conditions by RapiDot. The order is -, Negative control, +, Positive control and 0-36, sampling time points in $\mathrm{h}$; as depicted in the template.

In floc samples, the skim milk concentrated recombinant VP28 protein was detectable by RapiDot (Figure 2a) and the rVP28 transcript by PCR (Figure 2b) under both acidic and neutral conditions. RapiDot detected the rVP28 protein from $2 \mathrm{~h}$ to $36 \mathrm{~h}$ in acidic and $2 \mathrm{~h}$ to $24 \mathrm{~h}$ in neutral conditions. PCR detected the rVP28 transcript from $2 \mathrm{~h}$ to $36 \mathrm{~h}$ in acidic conditions whereas in neutral conditions it was not discernible throughout the flocculation period.

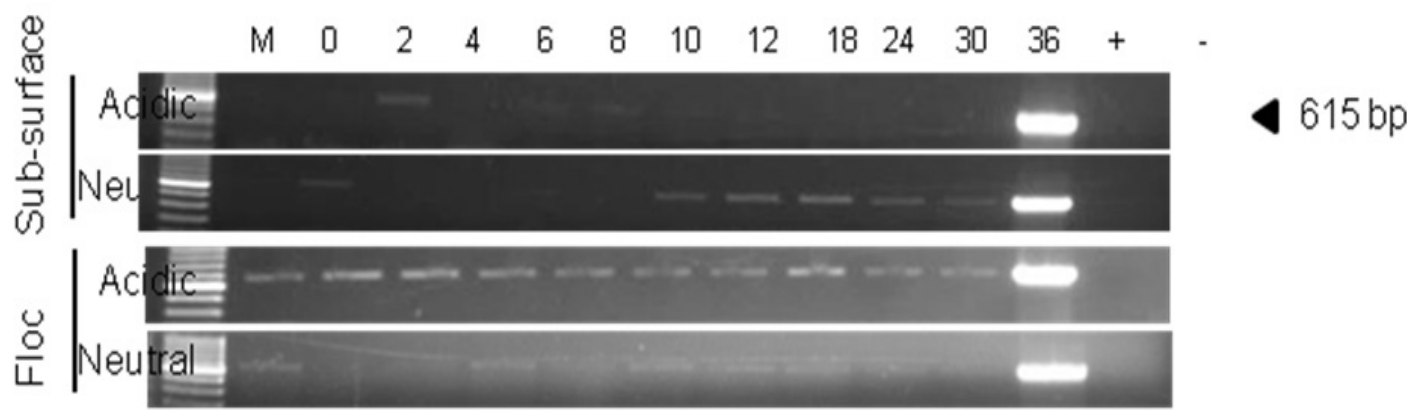

Figure 2b: PCR analysis of the recombinant VP28 concentrated by skim milk flocculation in sub-surface and floc samples. Amplification of the rVP28 transcript amplicons at $615 \mathrm{bp}$ in sub-surface and floc samples by 1-step PCR following flocculation by skim milk under acidic and neutral conditions. Lanes: M, Molecular marker; 0-36, Sampling time points in h; +, Positive control and -, Negative control.

\section{WSSV from experimentally infected shrimp in seawater concentrates to floc by skim milk}

WSSV from experimentally infected shrimp water in 2 and $1 \mathrm{~L}$ beakers, and $50 \mathrm{~mL}$ measuring cylinders was successfully concentrated by flocculation using $0.01 \%$ skim milk. The WSSV was not detectable by RapiDot (Figure 3) and 1-step
PCR (Figure 4) from $6 \mathrm{~h}$ to $36 \mathrm{~h}$ in sub-surface samples from all of the different laboratory glassware under acidic and neutral conditions. In contrast, nested PCR detected the virus in subsurface samples under acidic and neutral conditions with low gel band intensity at different time intervals in 2 and $1 \mathrm{~L}$ beakers, and $50 \mathrm{~mL}$ measuring cylinders (Figure 4). In floc samples, the WSSV was detectable by RapiDot (Figure 3), 1-step and nested 


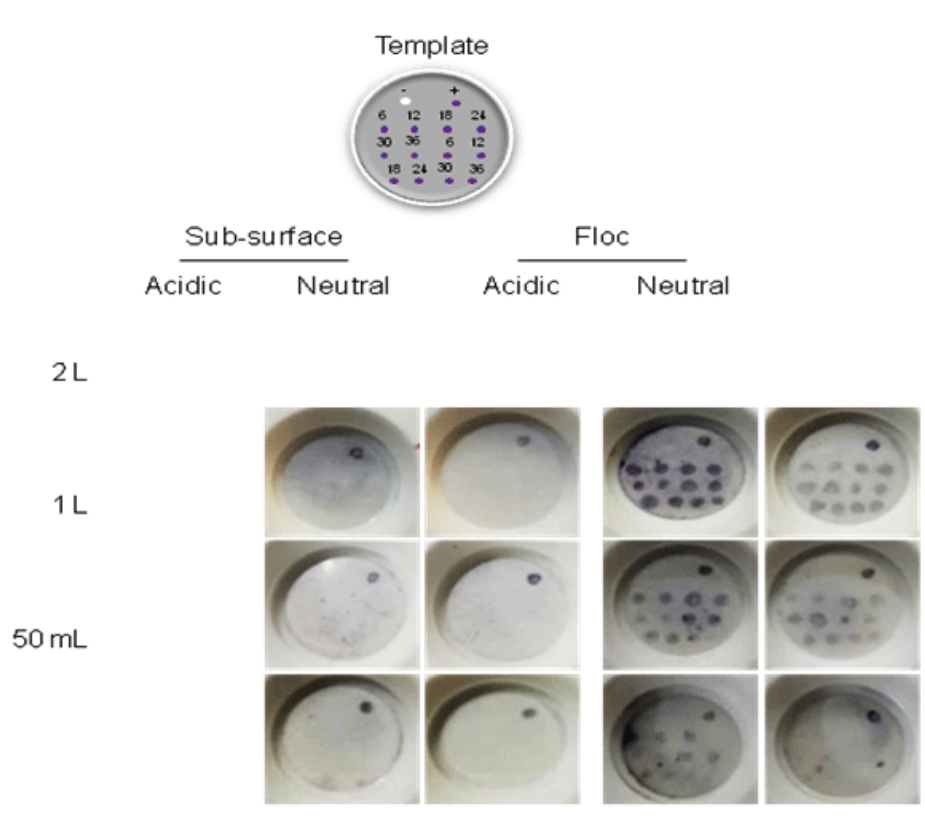

Figure 3: RapiDot analysis of WSSV concentrated by skim milk flocculation in sub-surface and floc samples from seawater experimentally inoculated with virus. Appearance of purple blue dots showing the presence of WSSV in sub-surface and floc samples under acidic and neutral conditions from 2 $\mathrm{L}, 1 \mathrm{~L}$ and $50 \mathrm{~mL}$ laboratory glassware. The order is -, Negative control, +, Positive control and 6-36, sampling time points in h, as depicted in duplicate in the template.

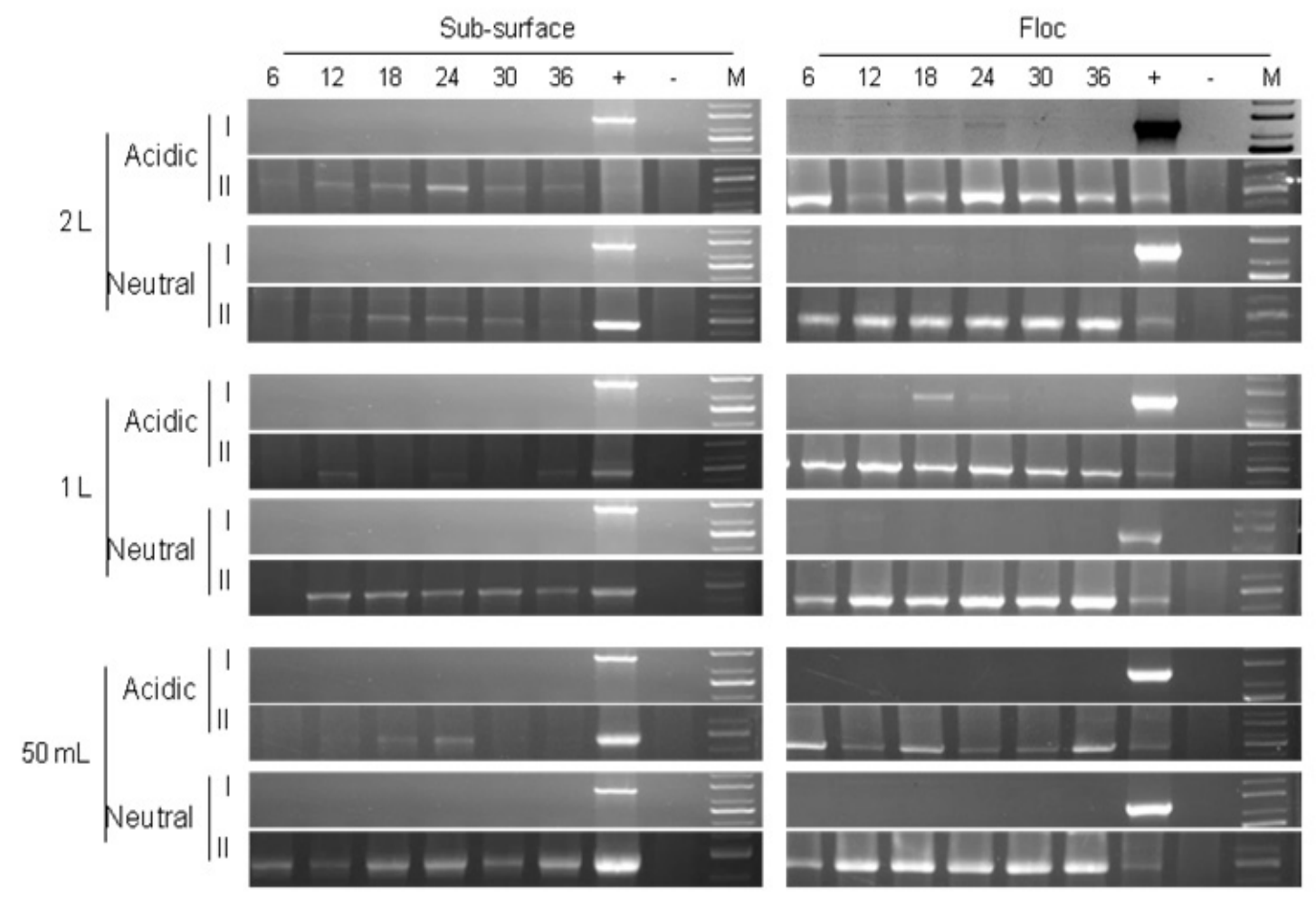

Figure 4: PCR analysis of WSSV concentrated by skim milk flocculation in sub-surface and floc samples from seawater experimentally inoculated with virus. Amplification of WSSV-specific amplicons of $1447 \mathrm{bp}$ by 1-step and $941 \mathrm{bp}$ by nested PCR in sub-surface and floc samples under acidic and neutral conditions from $2 \mathrm{~L}, 1 \mathrm{~L}$ and $50 \mathrm{~mL}$ laboratory glassware. Lanes: 6-36, Sampling time points in h; +, Positive control; -, Negative control and M, Molecular marker.

Citation: Camerson DG, Shankar MK, Prakash Patil, et al. (2018) Skim Milk Flocculation Concentrates White Spot Syndrome Virus in Seawater for Detection Using A Monoclonal Antibody Based Flow-Through Assay. J Poul Fish Sci .2(1):1-8. 
PCR (Figure 4) in all the different laboratory glassware. The RapiDot dot intensities were more intense for the floc samples under acidic conditions in all the different laboratory glassware, compared to the neutral conditions, but these dot intensities were decreased over the flocculation period. In contrast, 1-step PCR detected WSSV with less intensity (1447 bp) under acidic conditions at $24 \mathrm{~h}$ for $2 \mathrm{~L}$ and $18 \mathrm{~h}$ for $1 \mathrm{~L}$ beaker floc samples, but not detected in $50 \mathrm{~mL}$ measuring cylinder floc samples from acidic and neutral conditions at any period of flocculation. Furthermore, nested PCR detected WSSV in acidic and neutral conditions for floc samples from 2 and $1 \mathrm{~L}$ beakers, and $50 \mathrm{~mL}$ measuring cylinders throughout the flocculation duration. In general, the gel band thickness and intensities were increased under neutral conditions while decreased over period of time for acidic conditions.

\section{Discussion}

Despite bio security measures being adopted for the management of WSSV, it continues to elicit huge loss to shrimp aquaculture. Hence, early detection of this virus, especially in water is paramount for its management and control [37]. However, numerous interacting biological, physical and chemical factors, including predation by higher organisms, sunlight inactivation, disinfection and proteolytic enzymes in the natural aquatic environment are known to reduce the viral copy numbers $[38,39]$. This low copy number of WSSV in natural water hampers its detection and can only be solved by concentrating the virus from water. In the present study, attempts have been made to develop a simple method to concentrate the WSSV using skim milk flocculation and its detection by MAb based RapiDot. In preliminary experiments, the lowest dilution, in which RapiDot detected the recombinant VP28 protein, was used to determine the volume taken from therVP28 stock of WSSV for concentrating the rVP28 protein from water by flocculation using skim milk RapiDot detected the rVP28 protein of WSSV in sub-surface and floc samples under both acidic and neutral conditions. PCR could detect the rVP28 transcript of WSSV in sub-surface samples under both acidic and neutral conditions while in floc samples, PCR could detect only under acidic conditions. VP28 protein is one of the major coat proteins of WSSV that implicates in virulence [7] and has been widely used to detect WSSV from the shrimp homogenate $[40,41,34,35]$.

The concept of concentrating WSSV by skim milk flocculation was further evaluated by simulating the WSD outbreak in the laboratory aquaria through experimental infection studies using P. monodon. RapiDot, 1-step and nested PCR detected the WSSV in floc samples from acidic and neutral conditions, but the intensity of dots and gel bands varied with the flocculation duration. Normally, concentrating environmental viruses from water requires large volumes of water i.e. groundwater and tap water need about $100 \mathrm{~L}$ while recreational water $10 \mathrm{~L}$ for processing. In another study, WSSV was concentrated and detected by PCR after $>60 \mathrm{~L}$ of water was processed [24]. However, this study has demonstrated that WSSV can be concentrated by skim milk flocculation from less volume of infected water for detection. Additionally, similar results were observed in experimental infection studies and
PCR method. Nevertheless, RapiDot and nPCR can detect WSSV in apparently healthy shrimp and pond soil [34,42-44] with very low viral load which could not be detected in 1-step PCR.

Moreover, it was observed that flocculation of WSSV by skim milk was improved under acidic conditions, as indicated by high intensity dots in RapiDot and good amplification by 1-step and nested PCR. Similarly, observations were made earlier wherein the real time PCR (qPCR) of human and animal viruses showed more viral recovery when concentrated by skim milk under acidified environment $[19,20,45]$. The better performance of flocculation at $\mathrm{pH} 3.5$ could be attributed to the change in the isoelectric point of virus that made them aggregate and precipitate out of the water $[21,46]$. Though these results were found better under acidic conditions, but the requirement of acid and special equipment makes it impracticable for the farmers. Nevertheless, the concentration of WSSV under neutral conditions which is more farmer-friendly, simple, cheap and equally performed well can be recommended instead.

In conclusion, a one-step method for concentrating WSSV by skim milk flocculation has been developed in this study and enhanced detection of virus by RapiDot under acidic conditions. Furthermore, both the concentration and detection method that has been developed are rapid, simple, cheap and may be adaptable to field level as an early warning tool to monitor the dynamics of WSSV over-time in the aquatic environment before an outbreak.

\section{Acknowledgements}

This research study was supported by a revolving fund, a university grant from the Karnataka Veterinary Animal and Fisheries Sciences University (KVAFSU), Bidar. We thank the Africa Centre of Excellence (ACE II) in Aquaculture and Fisheries at Lilongwe University of Agriculture and Natural Resources (LUANAR) for supporting the publication of this manuscript.

\section{References}

1. Anderson K. Globalization's effects on world agricultural trade, 1960-2050. Phil Trans R Soc BBiol Sci. 2010;365(1554):3007-3021. doi: 10.1098/rstb.2010.0131

2. Anderson JL, Valderrama D, Jory D. Global shrimp production review. Global Aquaculture Advocate. 2014. Cited 2017 Oct 07. Available from: https://www.aquaculturealliance.org/wpcontent/ uploads/.../Day1_JimAnderson.pdf

3. Bostock J, Mc Andrew B, Richards R, Jauncey K, Telfer T, Lorenzen K, et al. Aquaculture: Global status and trends. Phil Trans R Soc BBiol Sci. 2010;365(1554):2897-2912. doi: 10.1098/rstb.2010.0170

4. Lightner DV. Status of shrimp diseases and advances in shrimp health management. Asian aquaculture VII. Fish health section, Asian Fisheries Society. 2011.

5. Lightner DV, Redman RM, Pantoja CR, Tang KFJ, Noble BL, Schofield $\mathrm{P}$, et al. Historic emergence, impact and current status of shrimp pathogens in the Americas. J Invertebr Pathol. 2012;110(2):174-183. doi: 10.1016/j.jip.2012.03.006

6. Flegel TW. Historic emergence, impact on current status of shrimp pathogens in Asia. J Invertebr Pathol. 2012;110(2):166-173. doi: 10.1016/j.jip.2012.03.004 
7. Yi G, Wang Z, Qi Y, Yao L, Qian J, Hu L. Vp28 of shrimp white spot syndrome virus is involved in the attachment and penetration into shrimp cells. J Biochem Mol Biol. 2004;37(6):726-734.

8. vanHulten MCW, Witteveldt J, Snippe M, Vlak JM. White spot syndrome virus envelope protein VP28 is involved in the systemic infection of shrimp. J Gen Virol. 2001;285(2):228-233. doi: 10.1006/ viro.2001.0928

9. Lo CF, Aoki T, Bonami JR, Flegel TW, Leu JH, Lightner DV, et al. Nimaviridae. In: Virus taxonomy: classification and nomenclature of viruses, Ninth report of the International Committee on Taxonomy of Viruses, King AMQ, Adams MJ, Carstens EB, Lefkowitz EJ, editors. Elsevier Academic Press; 2012. p. 229-234.

10. Escobedo-Bonilla CM, Alday-Sanz V, Wille M, Sorgeloos P, Pensaert MB, Nauwynck HJ. A review on the morphology, molecular characterization, morphogenesis and pathogenesis of white spot syndrome virus. J Fish Dis. 2008;31(1):1-18. DOI: 10.1111/j.13652761.2007.00877.x

11. Tuyena NX, Verreth J, VlakdJM, de Jong MCM. Horizontal transmission dynamics of White spot syndrome virus by cohabitation trials in juvenile Penaeus monodon and P. vannamei. Prev Vet Med. 2014;117(1):286-294. doi: 10.1016/j.prevetmed.2014.08.007

12. Hoa TTT, Zwart MP, Phuong NT, Vlak JM, de Jong MCM. Transmission of white spot syndrome virus in improved extensive and semiintensive shrimp production systems: a molecular epidemiology study. Aquaculture. 2011;313(1-4):7-14.

13. OIE. Immediate notification of WSSV, submitted date: 09/05/2012 OIE, Paris. [cited 2017 Jun. 30]; Available at: www.rr-africa.oie.int/ en/news/20120517.html

14. OIE. Immediate notification of WSSV, submitted date: 22/09/2011. OIE, Paris. [cited 2017 Jun. 30]; Available at: www.rr-africa.oie.int/ en/news/20120517.html

15. Saksida SM, Gardner I, Kent ML. Transmission of infectious agents between wild and farmed fish. In: Woo P TK, Bruno DW, Lim LHS, editors. Diseases and disorders of finfish in cage culture. Wallingford: CABI; 2014

16. Kurath G, Winton J. Complex dynamics at the interface between wild and domestic viruses of finfish. Curr Opin Virol. 2011;1(1):73-80.

17. Esparza-Leal HM, Escobedo-Bonilla CM, Casillas-Hernandez R, Alvarez-Ruiz P, Portillo-Clark G, Valerio-Garcia RC. Detection of white spot syndrome virus in filtered shrimp-farm water fractions and experimental evaluation of its infectivity in Litopenaeus vannamei. Aquaculture. 2009;292(1-2):16-22.

18. Pérez-Méndez A, Chandler JC, Bisha B, Goodridge LD. Concentration of enteric viruses from tap water using an anion exchange resinbased method. J Virol Methods. 2014;206:95-98. doi: 10.1016/j. jviromet.2014.05.025

19. Calgua B, Rodriguez-Manzano J, Hundesa A, Sũnen E, Calvo M, Bofill-Mas S, et al. New methods for the concentration of viruses from urban sewage using quantitative PCR. J Virol Methods. 2013;187(2):215-221. doi: 10.1016/j.jviromet.2012.10.012

20. Calgua B, Fumian T, Rusiñol M, Rodriguez-Manzano J, Mbayed VA, Bofill-Mas S, et al. Detection and quantification of classic and emerging viruses by skimmed-milk flocculation and PCR in river water from two geographical areas. Water Res. 2013;47(8):27972810. doi: 10.1016/j.watres.2013.02.043
21. Calgua B, Mengewein AA, Grünert A, Bofill-Mas S, ClementeCasares $\mathrm{P}$, Hundesa A, et al. Development and application of a onestep low cost procedure to concentrate viruses from seawater samples. J Virol Methods. 2008;153(2):79-83. DOI: 10.1016/j. jviromet.2008.08.003

22.Zhang H, Chen Q, Chen Z. A simple and efficient method for detecting avian influenza virus in water samples. J Virol Methods. 2014;199:124-12.

23. Bosch A, Sanchez G, Abbaszadegan M, Carducci A, Guix S, Le Guyader FS, et al. Analytical methods for virus detection in water and food. Food Anal Methods. 2011;4(1):4-12.

24.Alavandi SV, Bharathi RA, Kumar SS, Dinesh kumar N, Saravana kumar C, Rajan JJS. Tangential flow ultrafiltration for detection of white spot syndrome virus (WSSV) in shrimp pond water. J Virol Methods. 2015;218:7-13. DOI: 10.1016/j.jviromet.2015.03.001

25.Suzuki Y, Suzuki T, Kono T, Mekata T, Sakai M, Itami T. The concentration of white spot disease virus for its detection in sea water using a combined ferric colloid adsorption and foam separation based method. J Virol Methods. 2011;173(2):227-232. DOI: 10.1016/j.jviromet.2011.02.010

26. Hossain MS, Otta SK, Chakraborty A, Kumar SH, Karunasagar I, Karunasagar I. Detection of WSSV in cultured shrimp, captured brooders, shrimp post larvae and water samples in Bangladesh by PCR using different primers. Aquaculture. 2004;237(1-4):59-71.

27. Quang ND, Hoa PTH, Da TT, Anh PH. Persistence of white spot syndrome virus in shrimp ponds and surrounding areas after an outbreak Environ. Monit Assess. 2009;156(1-4):69-72. DOI: 10.1007/s10661-008-0463-7

28.Amrita R, Sathish RP, Naveen KumarBT, Abhiman PB, Prakash P, Ramesh KS, et al. Concentrating white spot syndrome virus by alum for field detection using a monoclonal antibody based flow-through assay. J Biol Methods. 2016;3(2):39-44.

29. Mohammed SJ, Muyibi SA, Oseni MI. Comparative Study of the Use of Coagulants in Biologically Treated Palm Oil Milleffluent (POME). Adv in Nat Appl. Sci. 2012;6(5).646-650.

30. Renault F, Sancey B, Badot PM, Crini G. Chitosan for coagulation/ flocculation process-An ecofriendly approach. Eur Polym J. 2009;45(5):1337-1348.

31. OIE. White spot disease. In: Manual of Diagnostic Tests for Aquatic Animals 2017. Cited 2017 Oct 10. Available from: http://www. oie.int/fileadmin/Home/eng/Health_standards/aahm/current/ chapitre_wsd.pdf

32.Lo C.F, Ho CH, Peng S, Chen CH, Hsu HC, Chiu YL, et al. White spot syndrome baculovirus (WSBV) detected in cultured and captured shrimp, crab and other arthropods. Dis Aquat Org. 1996;27(3):215225. doi:10.3354/dao027215

33.Kulkarni A, Rombout JH, Singh IS, Sudheer NS, Vlak JM, Caipang CM, et al. Truncated VP28 as oral vaccine candidate against WSSV infection in shrimp: an uptake and processing study in the midgut of Penaeus monodon. Fish Shellfish Immunol. 2013;34(1):159-166. doi: 10.1016/j.fsi.2012.10.028

34.Patil R, Shankar KM, Kumar BTN, Kulkarni A, Patil P, Morger N. Development of a monoclonal antibody-based flow-through immunoassay (FTA) for detection of white spot syndrome virus 
(WSSV) in black tiger shrimp, Penaeus monodon. J Fish Dis. 2013;36(9):753-762. doi: 10.1111/jfd.12050

35. Yoganandhan K, Musthaq SS, Sudhakaran R, Balasubramanian G, Sahul Hameed AS. Temporal analysis of VP28 gene of Indian white spot syndrome virus isolate (WSSV) in different crustacean hosts. Aquaculture. 2006;253:71-81.

36.Xie X, Li H, Xu L,Yang F. A simple and efficient method for purification of intact white spot syndrome virus (WSSV) viral particles. Virus Res. 2005;108(1-2):63-67. doi: 10.1016/j.virusres.2004.08.002

37. Sahoo AK, Mohan CV, Shankar KM, Corsin F, Turnbull JF, Thakur $\mathrm{PC}$, et al. Clinical white spot disease status in Penaeus monodon during the middle of the culture period-its epidemiological significance. J Fish Dis. 2010;33(7):609-615. doi: 10.1111/j.13652761.2010.01144.x

38.Verbyla ME, Mihelcic JR. A review of virus removal in waste water treatment pond systems. Water Res. 2015;71:107-124. doi 10.1016/j.watres.2014.12.031

39. Fong TT, Lipp EK. Enteric Viruses of Humans and Animals in Aquatic Environments: Health Risks, Detection, and Potential Water Quality Assessment Tools. Microbiol Mol Biol Rev. 2005;69(2):357-371. doi 10.1128/MMBR.69.2.357-371.2005

40.Kulabhusan PK, Rajwade JM, Sahul Hameed AS, Paknikar KM. Lateral flow assay for rapid detection of white spot syndrome virus (WSSV) using a phage-displayed peptide as bio-recognition probe
Appl Microbiol Biotechnol. 2017;101(11):4459-4469. doi: 10.1007/ s00253-017-8232-6

41. Mendoza-Cano FF, Sánchez-Paz A. Development and validation of a quantitative real-time polymerase chain assay for universal detection of the White Spot Syndrome Virus in marine crustaceans. Virol J. 2013;10:186-196. doi: 10.1186/1743-422X-10-186

42. Natividad KDT, Nomura N, Matsumura M. Detection of WSSV DNA in pond soil using a 2-step nested PCR.J Virol Methods. 2008;149(1):2834. DOI: 10.1016/j.jviromet.2008.01.013

43.Jiang XF, Lu L, Chen YG, Chan SM, He JG. Comparison of a novel in-situ polymerase chain reaction (ISPCR) method to other methods for white spot syndrome virus (WSSV) detection in Penaeus vannamei. Dis Aquat Org. 2005;67(1-2):171-176. DOI: 10.3354/dao067171

44.0tta SK, Karunasagar I, Karunasagar I. Detection of monodon baculovirus and whitespot syndrome virus in apparently healthy Penaeus monodon postlarvae from India by polymerase chain reaction. Aquaculture. 2003;220(1-4):59-67.

45.Bofill-Mas S, Calgua B, Clemente-casaresP, La Rosa G, Iaconelli M, Muscillo M,et al. Quantification of human adenoviruses in European recreational waters. Food Environ Virol. 2010;2(2):101-109.

46.Calgua B, Barardi CR, Bofill Mas S, Rodriguez-Manzano J, Girones R. Detection and quantitation of infectious human adenoviruses and JC polyomaviruses in water by immunofluorescence assay. J Virol Methods. 2011;171(1):1-7. doi: 10.1016/j.jviromet.2010.09.013 